\title{
Biostratigraphy of the Gurpi Formation (Zagros Basin, western Iran) based on planktonic foraminifera
}

\author{
Atusa Honarmand, Mohammad Vahidinia, Mohammad Hosein Mahmudy Gharaie, \\ Meysam Shafiee Ardestani
}

Faculty of Science, Department of Geology, Ferdowsi University of Mashhad, Mashhad, Iran; e-mails: atusa.honarmand@yahoo.com; Vahidinia@ferdowsi.um.ac.ir (corresponding author); Meysam.shafieeardestani@mail.um.ac.ir

(Accepted in revised form: April, 2020)

\begin{abstract}
Micropalaeontological and biostratigraphic studies of the Gurpi Formation were carried out at the Kuhe-Surgah section (Zagros Basin, Iran). In this research, 62 species of planktonic foraminifera, belonging to 23 genera, were recognized and used to describe the following zones: 1) Contusotruncana plummerae Interval Zone; 2) Radotruncana calcarata Total Range Zone; 3) Globotruncanella havanensis Partial Range Zone; 4) Globotruncana aegyptiaca Interval Zone; 5) Gansserina gansseri Interval Zone; 6) Contusotruncana contusa Interval Zone; 7) Abathomphalus mayaroensis Interval Zone; 8) Pseudoguembelina hariaensis Interval Zone; 9) Pseudotextularia elegans Interval Zone; 10) Parvularugoglobigerina eugubina Total Range Zone; 11) Parasubbotina pseudobulloides Interval Zone; and 12) Praemurica unicinata Interval Zone. Based on the ranges of planktonic foraminifera, the age of the Kuhe-Surgah section was estimated to be middle Campanian-late Danian.
\end{abstract}

Honarmand, A., Mohammad, M., Gharaie, M.H.M., Ardestani, M.S. 2020. Biostratigraphy of the Gurpi Formation (Zagros Basin, western Iran) based on planktonic foraminifera. Geologica Balcanica 49 (1), 53-66.

Keywords: Gurpi Formation, Kuhe-Surgah section, planktonic foraminifera, Zagros Basin, Iran.

\section{INTRODUCTION}

The Zagros Fold-Thrust Belt, which extends for about $1800 \mathrm{~km}$ through Iraq and SW Iran, is a continent-continent, NW-SE trending, collisional orogenic belt between the African-Arabian plate and the Iranian block (Berberian and King, 1981; Koyi, 1988). This long mountain range constitutes a section of a folded belt of the Alpine-Himalayan orogenic system and spreads from the East Anatolian fault, in eastern Turkey, to the Makran range in southern Iran (Mouthereau, 2011). The Lorestan Province, which geographically takes part of this belt, has a long history of hydrocarbon exploration and production. The first hydrocarbon exploration and drilling activities in the Middle East started in this area (Motiee, 1994). The Upper Cretaceous marine sediments occur in different sedimentary basins in Iran, but one of their main outcrops can be found in the Zagros Basin of Lorestan. The Gurpi Formation is an important part of oil source rocks in the Zagros Basin, with variable age, ranging from the Santonian to the Paleocene (Aghanabati, 2004). The type section for this formation is in the Lali oil field in the northeast of Masjed Soleiman, and the dominant lithology consists of grey shales/marlstones and clayey limestones, with a total thickness of 320 $\mathrm{m}$. The Gurpi Formation is underlain by the limestones of the Ilam Formation and covered by the shales of the Pabdeh Formation (James and Wynd, 1965). For this study, we selected the Kuhe-Surgah section of the Gurpi Formation and report planktonic foraminiferal zonation from this succession. The latter is correlated with four other successions of the Lorestan Province. To date, numerous studies on the Gurpi Formation in the Zagros Basin have been presented, including biostratigraphic studies based on planktonic foraminifera: Vaziri-Moghadam et 
al. (2013), in the Gardbishe Area; Hemmati-Nasab et al. (2008), in the Kavar section; Daneshian et al. (2009), in the east Kangan Port and Ivan well; Asgharian Rostami (2012), at the Mish-Khas section; Fereydoonpoor et al. (2014), at the sections of the Kuh-e Siah, Tang-e Bulfares and Aghar anticlines; Bakhshandeh et al. (2015), at the Banroshan section (Fazli, 2015) at the Kuh-e Heram and Kuh-e Nargh sections; Sadeghi and Darabi (2015), at the Maroon oil fields; Biranvand and Qaseminejad (2013), at the Daniel section; and Rahimi et al. (2018), at the Gandab Section. Relatively diverse and well-preserved planktonic foraminiferal assemblages were found in this study. These assemblages provide more precise biostratigraphic subdivision of the studied succession than the previously made attempts.

\section{LITHOLOGICAL BACKGROUND}

The studied stratigraphic section is located in the Kuhe-Surgah Anticline, E of the town of Ilam

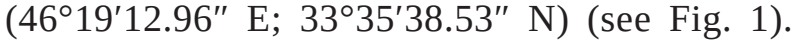
The rock units that constitute the Gurpi Formation consist of the following elements: 1) alternation of shales and limestones; 2) light grey shales with rare limestone interbeds, 300 m thick; 3) light brown limestones, $45 \mathrm{~m}$ thick (Seymare Limestone); 4) shales, 75 m thick; 5) light brown limestones, $88 \mathrm{~m}$ thick (Imam Hassan Limestone); 6) shales and limestones in alternation, $38 \mathrm{~m}$ thick; and 7) shales with a thickness of $66 \mathrm{~m}$. The entire succession corresponds to a total thickness of $612 \mathrm{~m}$. The lower boundary of the Gurpi Formation is conformable with the limestones of the Ilam Formation, whereas the upper boundary is marked by the first appearance of purple shales of the Pabdeh Formation (see Fig. 2).

\section{MATERIAL AND METHODS}

Three hundred and eleven samples, from both the soft sediments (shales) and the intercalated lime-
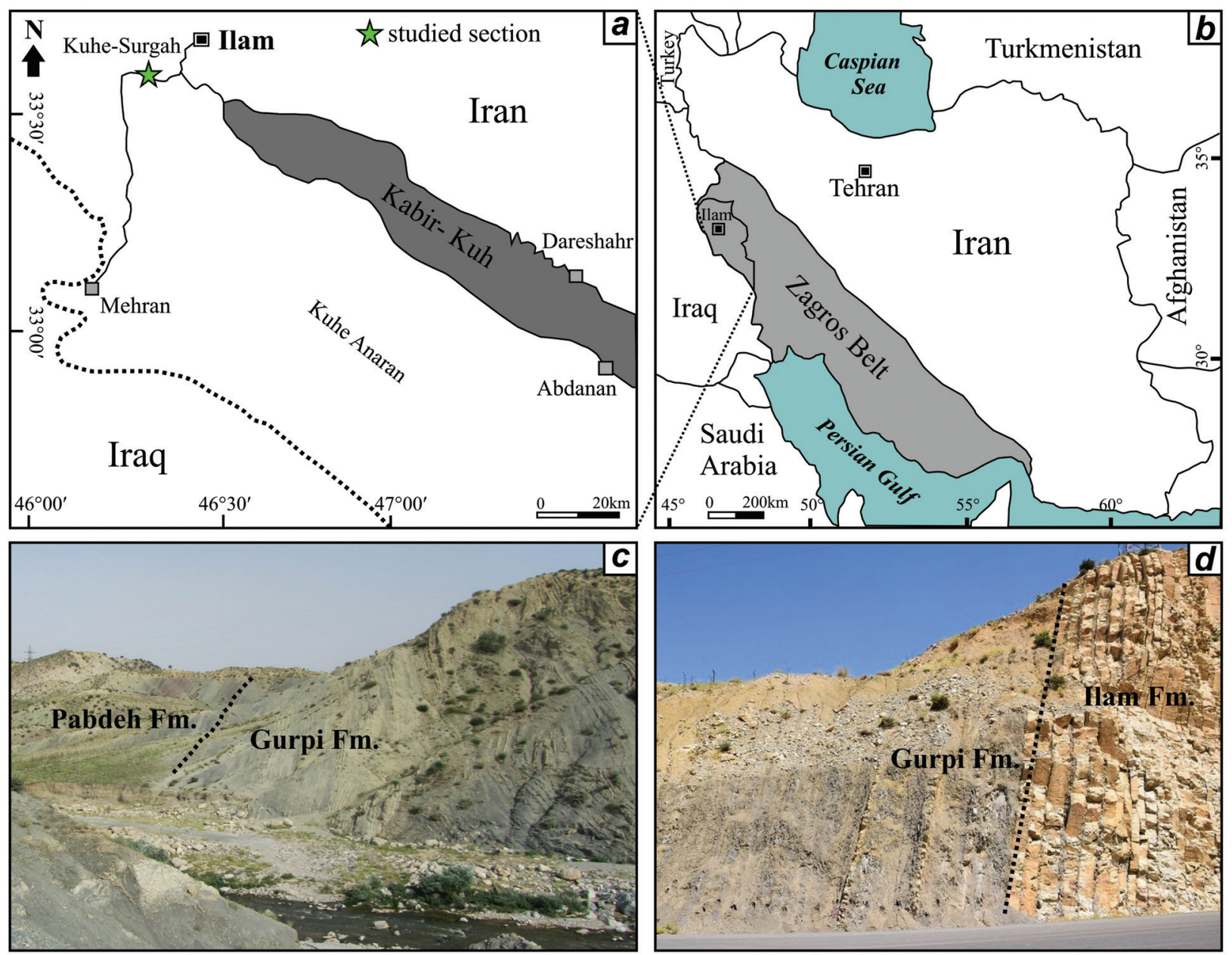

Fig. 1. $a, b$ ) Location maps of the Kuhe-Surgah section (Iran); $c, d$ ) Field photographs of the lower and upper boundaries of the Gurpi Formation in the Kuhe-Surgah section. 


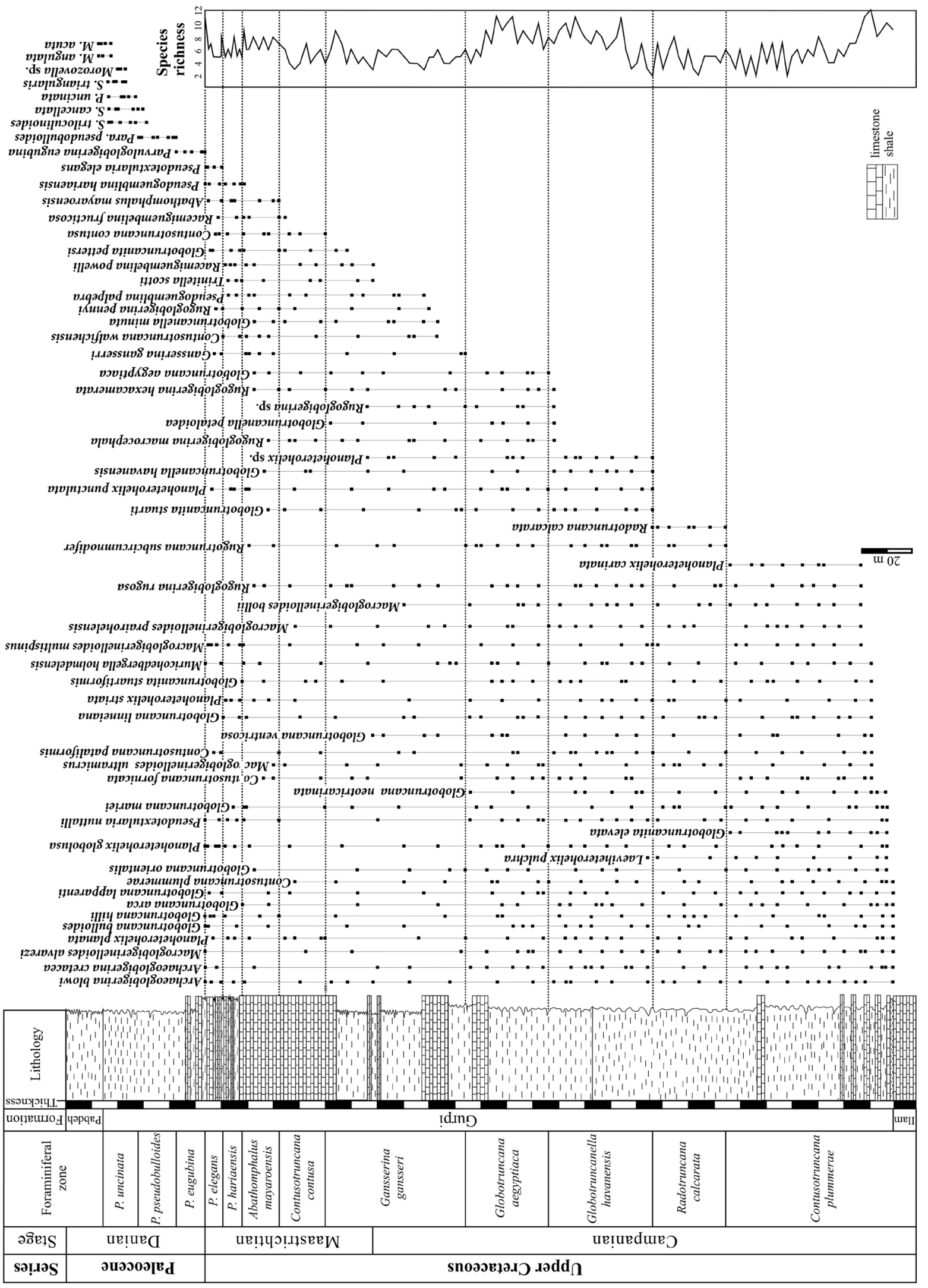


stone layers of the Gurpi Formation, were collected at the Kuhe-Surgah section. The sampling density between the base of the Gurpi Formation and the upper part of the Abathomphalus mayaroensis Zone is $4 \mathrm{~m}$; up-section, it was increased to $5 \mathrm{~m}$. Samples were transferred to the lab and about $200 \mathrm{~g}$ of each sample was crushed into small particles and placed in pure water for 2 days. Following the methodology of Zepeda (1998), 10\% solution of hydrogen peroxide was also added. Washing was performed on $70 \mu \mathrm{m}, 150 \mu \mathrm{m}$ and $230 \mu \mathrm{m}$ mesh. After the separation of microfossils under the optical microscope (Sa-Iran ZSM1001), the planktonic foraminifera were placed in special cells, and then they were taxonomically identified. Taxonomic concepts follow those of Postuma (1971), Caron (1985), Robaszynski and Caron (1979, 1995), Premoli Silva et al. (2003), and Premoli Silva and Verga (2004). Finally, washed residues were picked and micrographs of selected foraminiferal taxa were taken with a Scanning Electron Microscope (SEM) (Leo 1450VP) in the Central Laboratory of Ferdowsi University of Mashhadand.

\section{FORAMINIFERAL BIOSTRATIGRAPHY}

In this study, 23 genera and 62 species of planktonic foraminifera were identified. On this basis, a continuous succession of 12 Upper Cretaceous-Paleocene foraminiferal zones, from the Campanian to the Danian, is herein described (see Fig. 2; see also Figs 3, 4). The definitions of the zones follow those of Caron (1985), Sliter (1989), Abdel-Kireem et al. (1995), Robaszynski and Caron (1995), Yıldız and Özdemir (1999), Robaszynski et al. (2000), Dimitrova and Valchev (2007), Darvishzad et al. (2007) and Premoli Silva and Verga (2004). The biozonation used in this study is also similar to those of Premoli Silva et al. (2003) and Coccioni and Premoli Silva (2015).

\section{Contusotruncana plummerae Interval Zone}

This zone spans the uppermost part of the Ilam Formation and the lower part of the Gurpi Formation, and its thickness is $120 \mathrm{~m}$. The zone was defined as the interval between the first occurrence) FO) of Contusotruncana plummerae and the FO of Radotruncana calcarata. It corresponds to the middle Campanian. We follow the opinion of Petrizzo et al. (2011), who replaced the Globotruncana ventricosa Zone with the Contusotruncana plummerae Zone based on studies of the Bottaccione section (Italy) and Site 146 (central Atlantic Ocean). The most important species in the Contusotruncana plummerae Zone include: Archaeoglobigerina blowi (Pessagno, 1967); A. cretacea (d'Orbigny, 1840); Contusotruncana fornicata (Plunner, 1931); C. patelliformis (Gandolfi, 1955); Globotruncana arca (Cushman, 1926); G. bulloides (Vogler, 1941); Globotruncana hilli (Pessagno, 1967); Globotruncana linneiana (d’Orbigny, 1839); G. lapparenti (Brotzen,1936); G. mariei (Banner \& Blow, 1960); G. orientalis (El Naggar, 1966); G. ventricosa (White, 1928); Globotruncanita stuartiformis (Dalbiez, 1955); G. elevata (Brotzen, 1934); Macroglobigerinelloides bollii (Pessagno, 1967); M. multispinus (Lalicker, 1984); M. prairiehillensis (Pessagno, 1967); and Pseudotextularia nuttalli (Voorwijk, 1937).

\section{Radotruncana calcarata Total Range Zone}

This zone occurs in the light grey shales of the lower part of the Gurpi Formation, and it is $56 \mathrm{~m}$ thick. It corresponds to the total range of Radotruncana calcarata, which is late Campanian in age. We follow the zonal definition of Herm (1962). The planktonic foraminiferal assemblages in this zone are similar to those from the previous zone. The most important species include: Archaeoglobigerina cretacea (d’Orbigny, 1840); Contusotruncana fornicata (Plummer, 1931); C. pateliformis (Gandolfi, 1955); Globotruncana arca (Cushman, 1926); G. linneiana (d'Orbigny, 1839); G. mariei (Banner \& Blow, 1960); Globotruncanita stuartiformis (Dalbiez, 1955); Macroglobigerinelloides bollii (Pessagno, 1967); M. prairiehillensis (Pessagno, 1967); M. multispinus (Lalicker, 1948); Planoheterohelix globulosa (Ehrenberg, 1840); Rugotruncana subcircumnodifer (Gandolfi, 1955); and Rugoglobigerina macrocephala (Bronnimann, 1952).

Fig. 3. Representative foraminifer species from the Gurpi Formation. 1a-c) Globotruncana bulloides (Vogler,1941); 2a-c) Contusotruncana contusa (Cushman,1926); 3a-c) Contusotruncana fornicata (Plummer, 1931); 4a-c) Macroglobigerinelloides prairiehillensis (Pessagno 1967); 5a-c) Contusotruncana plummerae (Gandolfi,1955); 6a-c) Globotruncana neotricarinata (Petrizzo, Falzoni \& Premoli Silva 2011); 7a-c) Globotruncana aegyptiaca (Nakkady,1950). Scale bar same for all images. 


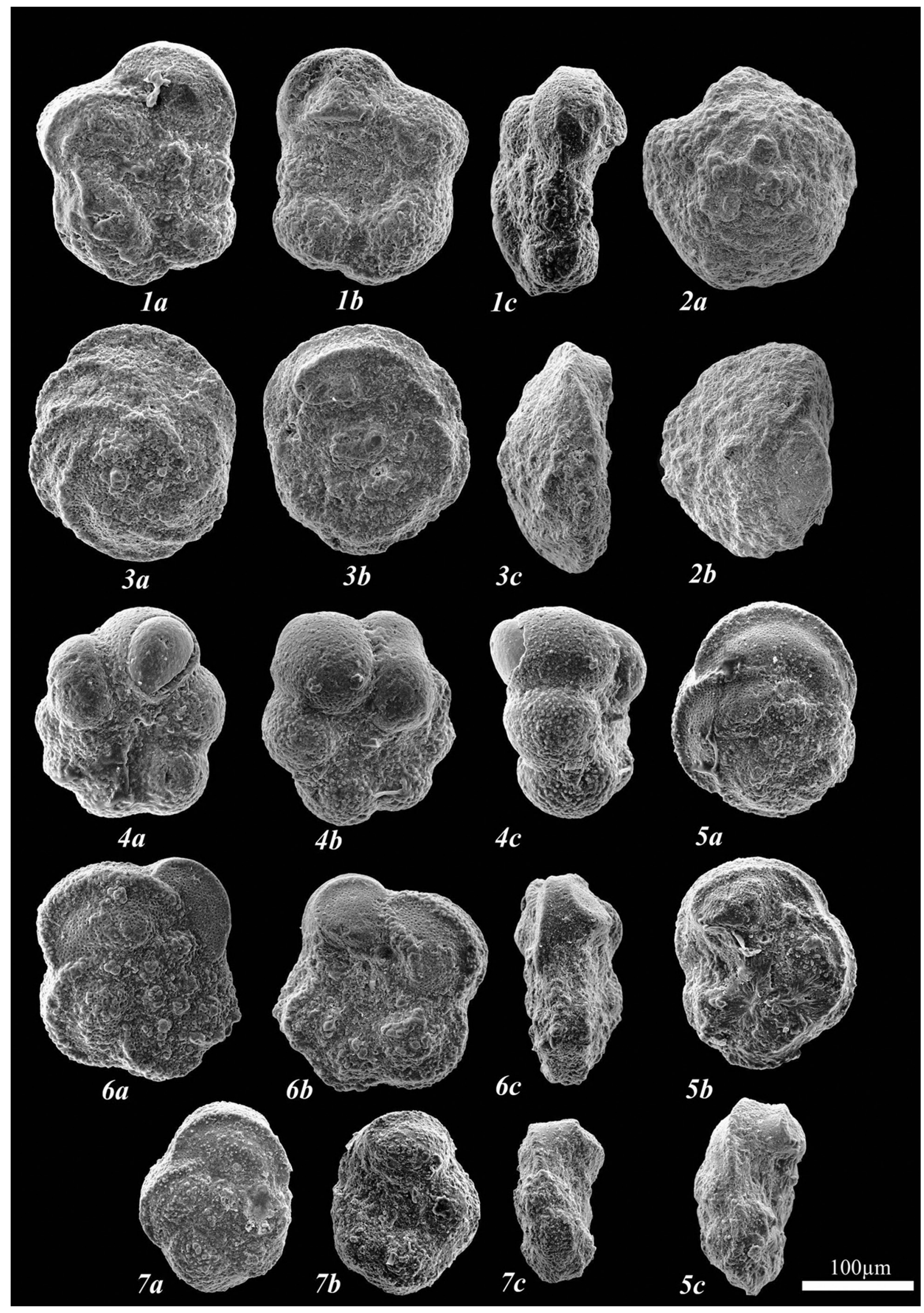




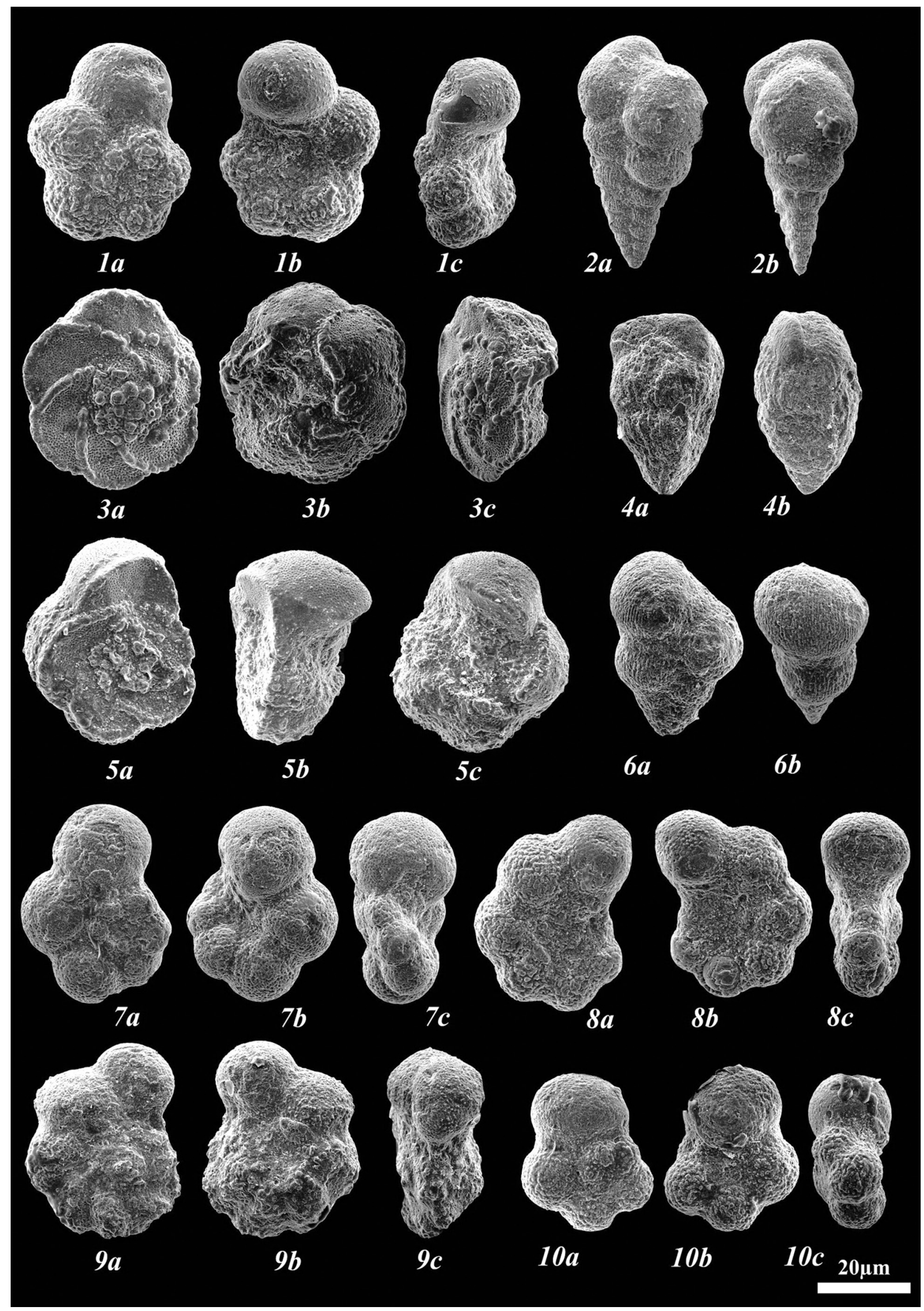


Fig. 4. Representative foraminifer species from the Gurpi Formation. 1a-c) Rugoglobigerina hexacamerata (Bronnimann,1952); 2a, b) Planoheterohelix moremani (Cushman, 1938); 3a-c) Globotruncanita pettersi (Gandolfi, 1955); 4a, b) Pseudotextularia elegans (Rzehak,1891).; 5a-c) Gansserina gansseri (Bolli, 1951); 6a-c) Planoheterohelix globulosa (Ehrenberg, 1840); 7a-c) Parasubbotina pseudobulloides (Plummer,1926); 8a, b) Macroglobigerinelloides bollii (Pessango,1967); 9a-c) Parvularugoglobigerina eugubina (Luterbacher \& Premoli Silva, 1964); 10a, b) Rugoglobigerina macrocephala (Brönnimann, 1952). Scale bar same for all images.

\section{Globotruncanella havanensis Partial Range Zone}

This zone occurs in the light grey shales of the lower part of the Gurpi Formation. It is $84 \mathrm{~m}$ thick. The zone represents an interval, with Globotruncanella havanensis, between the last occurrence (LO) of Radotruncana calcarata and the FO of Globotruncana aegyptiaca. It corresponds to the upper Campanian (pars.). We follow the zonal definition of Caron (1978). The most important foraminiferal species in the zone include: Archaeoglobigerina cretacea (d'Orbigny, 1840); Contusotruncana fornicata (Plummer, 1931); C. pateliformis (Gandolfi, 1955); Globotruncana arca (Cushman, 1926); G. linneiana (d’Orbigny, 1839); G. ventricosa (Whit, 1928); Globotruncanita stuartiformis (Dalbiez, 1955); Globotruncanella havanensis (Voorwijk, 1937); Macroglobigerinelloides prairiehillensis (Pessagno, 1967); M. multispinus (Lalicker, 1948); Pseudotextularia nuttalli (Voorwijk, 1937); Rugotruncana subcircumnodifer (Gandolfi, 1955); Rugoglobigerina macrocephala (Broennimann, 1952); and R. rugosa (Plummer, 1926).

\section{Globotruncana aegyptiaca Interval Zone}

This zone corresponds to a 68-m thick interval of the Gurpi Formation, which consists of shales and limestones. This interval was defined between the FOs of Globotruncana aegyptiaca and Ganserina gansseri, and it is late Campanian in age. The zone was identified according to the definition of Caron (1985). The diagnostic foraminifera are: Globotruncana ventricosa (White, 1928); G. arca (Cushman, 1926); Globotruncanita stuarti (de Lapparent, 1918); G. stuartiformis (Dalbiez, 1955); Muricohedbergella holmdelensis (Olsson, 1964); Planoheterohelix globulosa (Ehrenberg, 1840); Pseudotextularia elegans (Rzehak, 1891); and Rugoglobigerina macrocephala (Bronnimann, 1952).

\section{Gansserina gansseri Interval Zone}

This zone occurs in a 106-m thick interval of the Gurpi Formation, which is comprised of shales and limestones. We follow the definition of Brönnimann (1952), according to which the zone spans the interval between the FOs of Gansserina gansseri and Contusotruncana contusa. This interval includes the Campanian/Maastrichtian boundary. The most important foraminifera include: Globotruncana arca (Cushman, 1926); G. linneiana (d'Orbigny, 1839); Globotruncanita stuartiformis (Dalbiez, 1955); Globotruncanita stuarti (de Lapparent, 1918); Pseudotextularia nuttalli (Voorwijk, 1937); P. elegans (Rzehak, 1891); Rugoglobigerina macrocephala (Brönnimann, 1952); R. rugosa (Plummer, 1926); and Trinitella scotti (Brönnimann, 1952). In this zone, the FOs of Contusotruncana walfichensis, Globotruncanella minuta and Trinitella scotti were also recognized. These bioevents, which were detected in the middle part of the zone, indicate the Campanian/Masstrichtian boundary.

\section{Contusotruncana contusa Interval Zone}

The zone corresponds to a 40-m thick interval of the Gurpi Formation, which consists of limestones (Imam Hassan Limestone). Following the definition of Li and Keller (1998a, b), the zone was identified by the FOs of Contusotruncana contusa and Abathomphalus mayaroensis. The diagnostic foraminifera are: Gansserina gansseri (Bolli, 1951); Globotruncana linneiana (d’Orbigny, 1839); Globotruncanita stuartiformis (Dalbiez 1955), G. stuarti (de Lapparent, 1918); Pseudotextularia nuttalli (Voorwijk, 1937); P. elegans (Rzehak, 1891); Rugoglobigerina macrocephala (Brönnimann, 1952); R. rugosa (Plummer, 1926); and Racemiguembelina powelli (Smith and Pessagno, 1973). Amongst them, G. gansseri is particularly abundant in the upper part of the zone. The LO 
of Globotruncanella petaloidea was recorded near the base of the zone.

\section{Abathomphalus mayaroensis Interval Zone}

This zone corresponds to a 30-m thick limestone interval in the upper parts of the Gurpi Formation. It was recognized according to the definition of Brönnimann (1952), i.e., between the FOs of Abathomphalus mayaroensis and Pseudoguembelina hariaensis. The zone is late Maastrichtian in age, following the definition of Li and Keller (1998a, b). The zonal assemblage includes: Contusotruncana contusa (Cushman, 1926); Gansserina gansseri (Bolli, 1951); Globotruncana aegyptiaca (Nakkady, 1950); G. arca (Cushman, 1926); G. linneiana (d’Orbigny, 1839); Globotruncanella havanensis (Voorwijk, 1937); Pseudoguembelina palpebra (Brönnimann \& Brown, 1953); Pseudotextularia elegans (Rzehak, 1891); P. nuttalli (Voorwijk, 1937); Racemiguembelina fructicosa (Egger, 1899); R. powelli (Smith and Pessagno, 1973); Rugoglobigerina hexacamerata (Brönnimann, 1952); R. macrocephala (Brönnimann, 1952); and $R$. rugosa (Plummer, 1926). The most important event in this biozone is the FO of Racemiguembelina fructicosa, which was recorded near the base of the zone.

\section{Pseudoguembelina hariaensis Interval Zone}

This zone corresponds to a 16-m thick interval of the Gurpi Formation, which consists of alternating shales and limestones. It is an interval between the FO of Pseudoguembelina hariaensis and the LO of Gansserina gansseri, as defined by Coccioni and Premoli Silva (2015). We should note that Globotruncana arca disappears in the middle part of this zone. In addition, the LOs of Globotruncana linneiana and Planoheterohelix striata at the top, as well as the continuous range of Gansserina gansseri and Contusotruncana contusa throughout the zone, should also be noted. The most important foraminiferal taxa of this biozone include: Abathomphalus mayaroensis (Bolli, 1951); Contusotruncana contusa (Cushman, 1926); Gansserina gansseri (Bolli, 1951); Globotruncana aegyptiaca (Nakkady, 1950); G. arca (Cushman, 1926); G. mariei (Banner and Blow, 1960); Pseudoguembelina palpebra (Brönnimann \& Brown, 1953); Pseudotextularia elegans (Rzehak, 1891); P. nuttalli (Voorwijk, 1937); Racemiguembelina fructicosa (Egger, 1899); R. powelli (Smith \& Pessagno, 1973); Rugoglobigerina hexacamerata (Brönnimann, 1952); R. macrocephala (Brönnimann, 1952); R. rugosa (Plummer, 1926); and Trinitella scotti (Brönnimann, 1952).

\section{Pseudotextularia elegans Interval Zone}

This zone occurs in the shales and limestones of the upper part of the Gurpi Formation. It is $12 \mathrm{~m}$ thick. According to Coccioni and Premoli Silva (2015), the zone is defined between the LO of Gansserina gansseri and the FO of Plummerita hantkeninoides and corresponds to the latest Maastrichtian. In our section, however, $P$. hantkeninoides was not recorded, and therefore the latest occurrence of $P$. elegans was used to determine the upper limit of the zone. The zonal association includes: Abathomphalus mayaroensis (Bolli, 1951); Contusotruncana contusa (Cushman, 1926); Gansserina gansseri (Bolli, 1951); Globotruncana aegyptiaca (Nakkady, 1950); G. arca (Cushman, 1926), G. mariei (Banner \& Blow, 1960); Pseudotextularia elegans (Rzehak, 1891); P. nuttalli (Voorwijk, 1937); Planoheterohelix globulosa (Ehrenberg, 1840); and Pseudoguembelina hariaensis (Nederbraght, 1991).

\section{Parvularugoglobigerina eugubina Total Range Zone}

This zone occurs in the shale-limestone alternation of the upper part of the Gurpi Formation. It is $24 \mathrm{~m}$ thick. As defined by Luterbacher and Premoli Silva (1964), the zone corresponds to the total range of Parvularugoglobigerina eugubina, which is earliest Danian in age. In our section, the zone was defined by the occurrence of Subbotina triloculinoides (Plummer, 1926) and S. cancellata (Blow, 1979).

\section{Parasubbotina pseudobulloides Interval Zone}

This zone occurs in the dark grey shales of the uppermost part of the Gurpi Formation and has a total thickness of $26 \mathrm{~m}$. It was defined by Premoli Silva et al. (2003) as framed by the LO of Parvularugoglobigerina eugubina and the FO of Praemurica uncinata and corresponds to the Danian (pars.). In the studied section, the zonal association includes Parvularugoglobigerina eugubina (Luterbacher \& Premoli Silva, 1964); Subbotina triloculinoides (Plummer, 1926); Subbotina cancellata (Blow, 1979); and Subbotina spp.

\section{Praemurica uncinata Interval Zone}

This zone occurs in the black shales of the uppermost part of the Gurpi Formation. It is $30 \mathrm{~m}$ thick. We follow the definition of Bolli (1957), according to which the zone is defined between the FOs of Praemurica uncinata and Morozovella angulata. It corresponds to the uppermost Danian. The most important foraminifera of the zone include Subbotina 
triangularis (White, 1928) and Subbotina triloculinoides (Plummer, 1926).

\section{CORRELATION WITH OTHER SECTIONS IN IRAN}

The following paragraphs represent a biocorrelation between the Kuhe-Surgah stratigraphic section and a few other sections of the Gurpi Formation in Lorestan, namely Banroshan (Bakhshandeh et al., 2015); North Kabir-Kuh Anticline (Ghourchayi et al., 2009); Amiran (Darabi et al., 2017); and Kavar (see also Fig. 5). The number of the biozones recognized in each section is compared with their correlates in the other sections and their ages were interpreted. This allows us to determine changes in the thickness of the biozones from the northwest to the southeast in Lorestan. Those variations in thickness can be due to sea level changes and/or tectonic influence in the Zagros basin and they will be the subject of another paper.

\section{Banroshan section}

Bakhshandeh et al. (2015) recognized 10 foraminiferal zones in this section, in the following order: 1) Globotruncanita elevata Partial Rang Zone; 2) Globotruncana ventricosa Interval Zone; 3) Globotruncanita calcarata Interval Zone; 4) Globotruncanella havanensis Partial Range Zone; 5) Globotruncana aegyptiaca Interval Zone; 6) Gansserina gansseri Interval Zone; 7) Contusotruncana contusa Interval Zone; 8) Abathomphalus mayaroensis Interval Zone; 9) Parasubbotina pseudobulloides Interval Zone; 10) Globanomalina pseudomenardii Interval Zone. This zonal succession corresponds to a total extent from the middle Campanian to the Paleocene (pars.).

\section{North Kabir-Kuh section}

According to Ghourchayi et al. (2009), 15 zones were defined in this section, as follows: 1) Globotruncanita elevata Partial Range Zone; 2) Globotruncana ventricosa Interval Zone; 3) Globotruncanita calcarata Interval Zone; 4) Globotruncanella havanensis Partial Range Zone; 5) Globotruncana aegyptiaca Interval Zone; 6) Gansserina gansseri Interval Zone; 7) Abathomphalus mayaroensis Interval Zone; 8) Parvularugoglobigerina eugubina Total Range Zone; 9) Parasubbotina pseudobulloides Interval Zone; 10) Morozovella trinidadensis Interval Zone; 11) Morozovella uncinata Interval Zone; 12) Morozovella angulata Interval Zone; 13) Planorotalites pusila Interval Zone; 14) Pla- norotalites pseudomenardii Total Range Zone; and 15) Morozovella velanscoensis Interval Zone. This zonal succession corresponds again to a total extent from the Campanian to the Paleocene.

\section{Amiran section}

Darabi et al. (2017) recognized seven zones in the Amiran section: 1) Globotruncanita elevata Partial Range Zone; 2) Globotruncana ventricosa Interval Zone; 3) Radotruncana calcarata Total Range Zone; 4) Globotruncanella havanensis Partial Range Zone; 5) Globotruncana aegyptiaca Interval zone; 6) Gansserina gansseri Interval Zone; and 7) Contusotruncana contusa Partial Range Zone. The zonal succession suggests early Campanian-middle late Maastrichtian age for this section.

\section{Kavar section}

This section, which was also studied by the present authors, and the results will be published in detail elsewhere, has similar biozonation to the KuheSurgah section. Comparing the Gurpi Formation in the Kuhe-Surgah section with the four other sections indicates that the base of the Gurpi Formation is time-transgressive between the middle and late Campanian in these sections. However, in the Kavar section, unlike the North Kabir-Kuh Anticline section, sediments of late Paleocene age have not been observed. At the Amiran section, lower Campanian sediments have also been observed. In all five sections, there is an increased presence of more calcareous lithologies (i.e., Imam Hassan and Seymare Limestones).

\section{DISCUSSION}

Planktonic foraminifera have proved to be vital in intercontinental biostratigraphy of the Upper Cretaceous and Paleogene (e.g., Bolli and Krasheninnikov, 1966; Gardin et al., 2001; Petrizzo, 2003; Coccioni and Premoli Silva, 2015). As plankton organisms have extensive geographical distribution and abundance in marine sediments, they are very useful for the purposes of correlation. Upper Cretaceous foraminifer biostratigraphy in the Tethys has been performed by various authors. One of the most important works in this regard is Caron's (1985), which was later revised by Robaszynski and Caron (1995). The latter two authors also correlated their zonation scheme with the stratigraphic distribution of heterohelicids established by Nederbragt (1990). $\mathrm{Li}$ and Keller (1998) divided the Maastrichtian in the Tethys realm into eight zones. Recently, Upper 


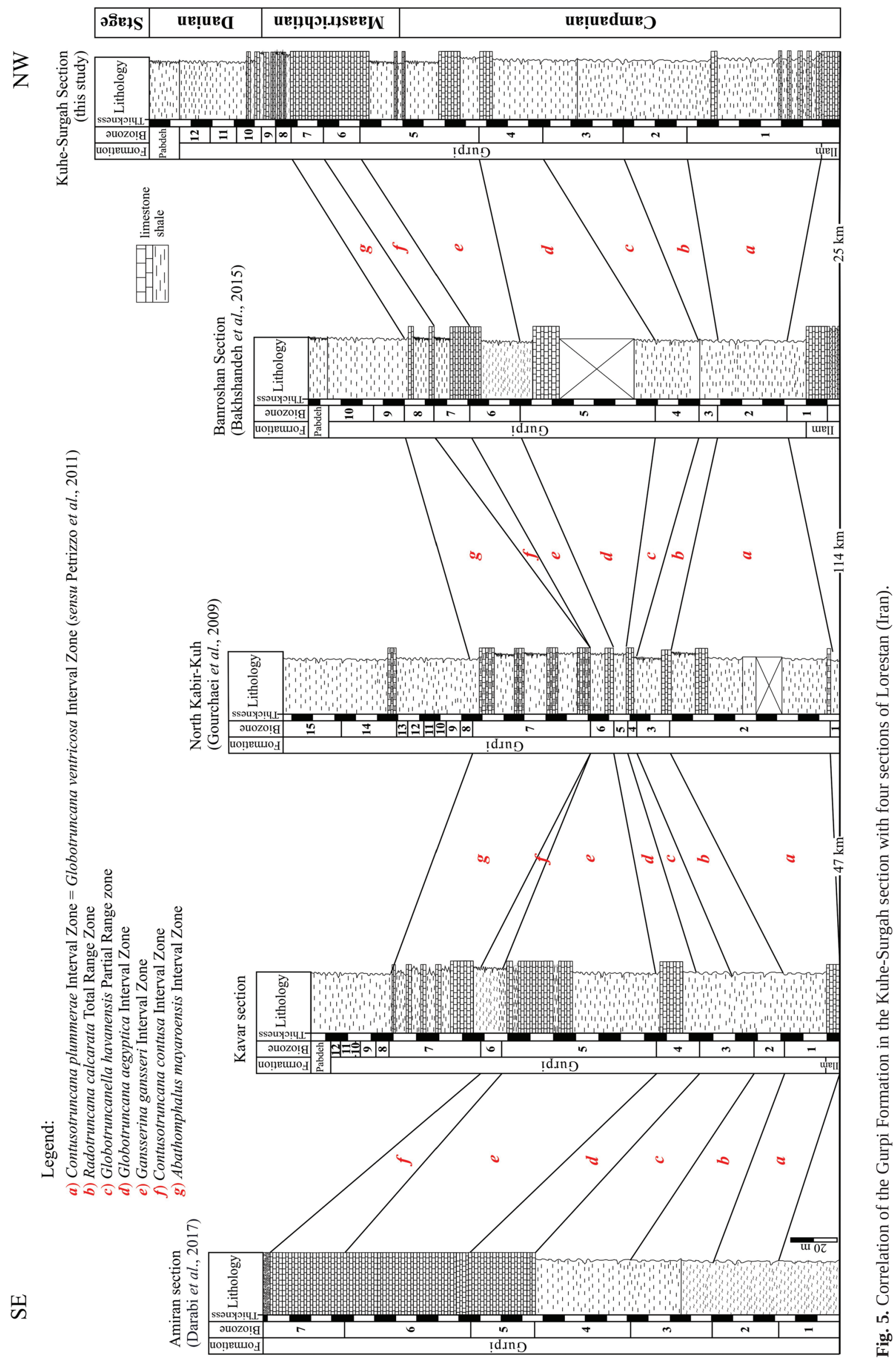


Cretaceous foraminifer biozones in the Tethys domain were reviewed by Coccioni and Premoli Silva (2015) (see Fig. 6).

In this study, we indicate the presence of the Contusotruncana plummerae Zone, based on Coccioni and Premoli Silva's (2015) definition. Many previous studies in the Tethyan realm, such as Caron (1985) and Li and Keller (1998), used the Globotruncana ventricosa Zone. However, Petrizzo et al. (2011), based on studies of the Bottaccione section (Italy) and Site 146 in the central Atlantic Ocean, replaced this zone with the Contusotruncana plummerae Zone. Fang et al. (2020) recorded the FO of Contusotruncana plummerae in the late Campanian.

In the past, Caron (1985) and Sliter (1989) proposed the base of the Radotruncana calcarata Zone to define the Campanian/Maastrichtian boundary.
In this research, however, the $R$. calcarata Zone is only late Campanian in age and does not contain the $\mathrm{C} / \mathrm{M}$ boundary.

Razmjooei et al. (2018) placed the C/M boundary near the FO of Gansserina gansseri and the LO of $U$. trifidus (calcareous nannofossil) at the Shahneshin section (Zagros Basin, Iran). However, we recorded the FOs of Contusotruncana walfichensis, Globotruncanella minuta and Trinitella scotti in the middle part of this zone and used these events to indicate the $\mathrm{C} / \mathrm{M}$ boundary.

According to Coccioni and Premoli Silva (2015), the Plummerita hantkeninoides Total Range Zone contains the extinctions of most of the Cretaceous planktonic foraminifera, and thus indicates Cretaceous/Paleogene boundary. However, in our research this zone was not detected.

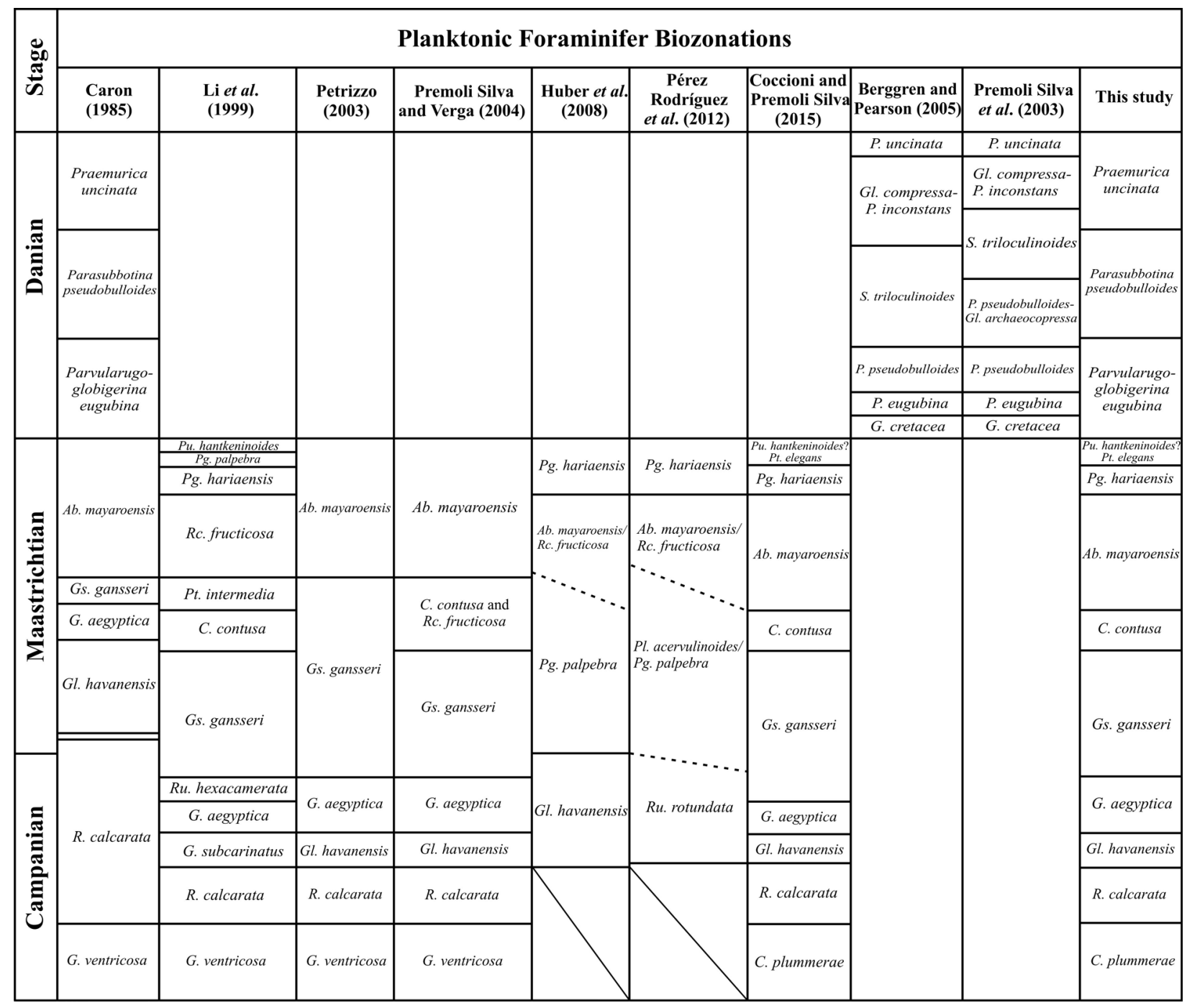

Fig. 6. Comparison of Campanian-Danian standard planktonic foraminifer biozonations. 


\section{CONCLUSION}

Analysis of the planktonic foraminifera in the Kuhe-Surgah section shows that the age of the Gurpi Formation here is middle Campanian-late Danian. Based on the presence of 62 planktonic foraminifer species belonging to 23 genera, we recognized the following zones: 1 ) Contusotruncana plummerae Interval Zone; 2) Radotruncana calcarata Total Range Zone; 3) Globotruncanella havanensis Partial Range Zone; 4) Globotruncana aegyptiaca Interval Zone; 5) Gansserina gansseri Interval Zone; 6) Contusotruncana contusa Interval Zone; 7) Abathomphalus mayaroensis Interval Zone; 8) Pseudoguembelina hariaensis Interval Zone; 9) Pseudotextularia elegans Interval Zone; 10) Parvularugoglobigerina eugubina Total Range Zone; 11) Parasubbotina pseudobulloides
Interval Zone; and 12) Praemurica unicinata Interval Zone. The Plummerita hantkeninoides Total Range Zone in the top of the Maastrichtian was not detected. Comparisons with five other sections in Lorestan show that the lower boundary of the Gurpi Formation is diachronous within the Campanian. The chronostratigraphic extent of this lithostratigraphic unit spans the lower Campanian to lower Paleocene, except for in the Amiran section, where only Cretaceous sediments have been reported so far.

\section{Acknowledgements}

This research was funded by the Ferdowsi University of Mashhad, Project number 47491. Dr Boris Valchev and one anonymous reviewer are thanked for critical reviews of the manuscript.

\section{REFERENCES}

Abdel-Kireem, M.R., Samir, A.M., Ibrahim, M.I.A. 1995. Upper Cretaceous planktonic foraminiferal zonation and correlation in the northern part of the Western Desert, Egypt. Neues Jahrbuch für Geologie und Paläontologie, Abhandlungen 198(3), 329-361.

Aghanabati, A. 2004. Geology of Iran. Geological survey of Iran, 568 pp. (in Persian).

Asgharian Rostami, M. 2012. Biostratigraphy and biogeography of the Gurpi Formation in Mish-Khas section, south of east Ilam province, based on foraminifera. Geosciences 85, 135-148.

Arz, J.A., Molina, E. 2001. Planktic foraminiferal quantitative analysis across the Campanian/Maastrichtian boundary at Tercis (Landes, France). In: Odin, G.S. (Ed.), The Campanian-Maastrichtian Stage Boundary-characterization at Tercis les Bains (France) and correlation with Europe and other continents. Developments in Paleontology and Stratigraphy 19, 338-348.

Bakhshandeh, L., Khosrow-tehrani, K., Mohtat, T., Vaziri, S.H., Keshani, F. 2015. Biozonation of the Gurpi Formatin at Banroushan Section, SW Ilam, based on Planktonic Foraminifera. Geosciences 95, 85-96 (in Persian).

Beiranvand, B., Ghasemi-Nejad, E. 2013. High resolution planktonic foraminiferal biostratigraphy of the Gurpi formation, K/Pg boundary of the Izeh zone, SW IRAN. Sociedade Brasileira de Paleontologia 16 (1), 5-26.

Berberian, M., King, G.C.P. 1981. Towards the paleogeography and tectonic evolution of Iran. Canadian Journal of Earth Sciences 18, 210-265.

Berggren, W.A., Pearson, P. 2005. Tropical to subtropical planktonik foraminiferal zonation of the Eocene and Oligocene. The Journal of Foraminiferal Research 35 (4), 279-298.

Bolli, H.M. 1957. Planktonic foraminifera from the Eocene Navet Formation and San Fernando formations in Trinidad, B.W.I. United States National Museum Bulletin 215, 155-172.
Bolli, H.M., Krasheninnikov, V.A. 1966. Problem in Paleogene and Neogene correlation based on planktonic foraminifera. Micropaleontology 23, 436-452.

Brönnimann, P. 1952. Globigerinidae from the Upper Cretaceous (Cenomanian-Maastrichtian) of Trinidad, B.W.I. Bulletin of American Palaeontology 34, 1-61.

Caron, M. 1978. Cretaceous planktonic foraminifera from DSDP Leg 40, Southeastern Atlantic Ocean. Initial Reports of the Deep Sea Drilling Project 40, 651-678

Caron, M. 1985. Cretaceous planktic foraminifera. In: Bolli, H.M., Saunders, J.B., Perch-Nielsen, K. (Eds), Plankton Stratigraphy. Cambridge University Press, Cambridge, 11-86.

Coccioni, R., Premoli Silva, I. 2015. Revised Upper AlbianMaastrichtian planktonic foraminiferal biostratigraphy and magneto - stratigraphy of the classical Tethyan Gubbio section (Italy). Newsletters on Stratigraphy 48 (1), 47-90.

Claudia, G., Cetean, A., Ramona, B., Michael, A., Kaminski, C., Filipescu, S. 2011. Integrated biostratigraphy and palaeoenvironments of an upper Santonian-upper Companian succession from the southern part of the Eastern Carpathians, Romania. Cretaceous Research 32, 575-590.

Darvishzad, B., Ghasemi-Nejad, E., Ghourchayi, S., Keller, G. 2007. Planktonic Foraminiferal Biostratigraphy and Faunal Turnover across the Cretaceous-Tertiary Boundary in Southwestern Iran. Journal of Sciences 18(2), 139-149.

Daneshian, J., Baghbani, D., Khosrow-tehrani, Kh., Fazli, L. 2010. Foraminiferal biostratigraphy of the Gurpi Formation and Ilam Formation in the east of Kangan port and Ivan well in the Persian Gulf, science quarterly journal. Geosciences 74, 157-162.

Darabi, G., Moghaddam, I.M., Sadeghi, A., Yusefi, B. 2017. Planktonic foraminifera and sea-level changes in the Upper Cretaceous of the Gurpi Formation, Lorestan Basin, SW Iran. Journal of African Earth Sciences 138, 201-218.

Dimitrova, E., Valchev, B. 2007. Attempt for Upper Cretaceous planktic foraminiferal zonation of the Srednogorie 
and Eastern Balkan Zones (Bulgaria). Geologica Balcanica 36 (1-2), 53-63.

Esmeray-Senlet, S, Özkan-Altiner, S., Altiner, D.G., Miller, K.G. 2015. Planktonic foraminiferal biostratigraphy, microfacies analysis, sequenge stratigraphy, and sea-level changes across the Cretaceous-Paleogene boundary in the Haymana basin, central Anatolia. Turkey. Journal of Sedimentary Research 85, 489-508.

Fereydoonpoor, M., Vaziri-Moghaddam, H., Ghabishawi, A., Taheri, A. 2014. Stratigraphy of the Gurpi Formation in Kuh-e Siah anticline and its comparison with Tang-e Bulfares and Aghar anticline sections. Sedimentary Facies Journal 7 (1), 83-106.

Fang, P.-Y., Xu, B., Mu, L., Zhu, Y.-H., Luo, H. 2020. New latest Coniacian to middle Campanian foraminiferal data from the lower Zongshan Formation in the Chaquiela section, Gamba, southern Tibet. Palaeoworld 29, 151-160.

Fazli, L. 2015. Planktonic foraminiferal biostratigraphy of the Gurpi Formation in south Qir, Fars. Geosciences 97, 11-20.

Gallala, N., Zaghbib-Turki, D., Arenillas, I., Antonio-Arz, J., Molina, E. 2009. Catastrophic mass extinction and assemblage evolution in planktic foraminifera across the Cretaceous/Paleogene (K/Pg) boundary at Bidart (SW France). Marine Micropaleontology 72, 196-209.

Gardin, S., Del-Panta, F., Monechi, S., Pozzi, M. 2001. A tethyan reference section for the Companian and Maastrichtian stages: the Bottaccione section (Central Italy). Review of the data and new calcareous nannofossil results. In: Odin, G.S. (Ed.), The boundary between the Companian and the Maastrichtian stages: Characterization at Tercis les Bains (France) and Correlations with Europe and other Continents. Development in Paleontology and Stratigraphy 19, 820-833.

Ghourchayi, Sh., Darvishzadeh, B., Ghasemi-Nejad, A. 2009. Biostratigraphy of Gurpi Formation in the north Kabirkuh based on foraminifera and correlation with other parts of the world. Journal of Geological Studies 1, 61-73.

Hadavi, F., Shukri, N. 2010. Nanostratigraphy of the Gurpi Formation in South of Ilam (Kavar Section). Journal of Sedimentary Facies 2, 217-225.

Hemmati-Nasab, M. 2008. Microbiostratigraphy and Sequence Stratigraphy of the Gurpi Formation in Kaaver Section, South of Kabir-kuh. MSc Thesis, University of Tehran, 177 pp.

Herm, D. 1962. Stratigraphische und micropaläontologische Untersuchungen der Oberkreide im Lattengebirge und im Nierental. Abhandlungen der Bayerischen Akademie der Wissenschaften 104, 1-119.

Huber, B.T., MacLeod, K.G., Tur, N.A. 2008. Chronostratigraphic framework for Late Campanian-Maastrichtian sediments on Blake Nose (subtropical North Atlantic). The Journal of Foraminiferal Research 38, 162-182.

James, G.A., Wynd, J.G. 1965. Stratigraphic nomenclature of Iranian oil consortium agreement area. AAPG Bulletin 49, 2182-2245.

Koyi, H.A. 1988. Experimental modeling of the role of gravity and lateral shortening in the Zagros mountain belt. $A A P G$ Bulletin 72, 1381-1394.

Li, L., Keller, G. 1998. Diversification and extinction in Campanian- Maastrichtian planktic foraminifera of northwestern Tunisia. Eclogae Geologicae Helvetiae 91, 75-102.

Li, L., Keller, G., Stinnesbeck, W. 1999. The Late Companian and Maastrichtian in northwestern Tunisia: palaeoenvironmental inferences from lithology, macrofauna and benthic foraminifera. Cretaceous Research 20, 231-252.

Luterbacher, H.P., Premoli Silva, I. 1964. Biostratigrafi a del limite Cretaceo-Terziario nell'Appennino centrale. Rivista Italiana di Paleontologia e Stratigrafia 70, 67-128.
Motiee, H. 1994. Stratigraphy of Zagros. Geological Survey of Iran, 536 pp. (in Persian).

Mouthereau, F. 2011. Timing of uplift in Zagros belt/Iranian plateau and accommodation of late Cenozoic Arabia-Eurasia convergence. Geological Magazine 184,738-756.

Nederbragt, A.J. 1990. Maastrichtian Heterohelicidae (planktonic foraminifera) from the North West Atlantic. Micropaleontology 8, 183-206.

Odin, G.S., Lamaurelle, M.A. 2001. The global Campanian/ Maastrichtian Stage Boundary. Episodes 24, 229-238.

Ozkan, S., Ozcan, E. 1999. Upper Cretaceous planktonic foraminiferal biostratigraphy from NW Turkey: calibration of the stratigraphic ranges of larger foraminifera. Geological Journal 34, 287-301.

Pérez-Rodríguez, I., Lees, J.A., Larrasoana, J.C., Arz, J.A., Arenillas, I. 2012. Planktonic foraminiferal and calcareous nannofossil biostratigraphy and magnetostratigraphy of the uppermost Companian and Maastrichtian at Zumaia, northern Spain. Cretaceous Research 37, 100-126.

Petrizzo, M.R. 2003. Late Cretaceous Planktonic foraminifera bioevents in the Tethys and in the southern Ocean record: An overview. The Journal of Foraminiferal Research 33, 330-337.

Petrizzo, M.R., Falzoni, F., Premoli Silva, I. 2011. Identification of the base of the lower-to-middle Companian Globotruncana ventricosa Zone: Comments on reliability and global correlations. Cretaceous Research 32, 387-405.

Postuma, J.A. 1971. Manual of Planktonic Foraminifera. Elsevier Publishing, Amsterdam, 420 pp.

Premoli Silva, I., Rettori, R., Verga, D. 2003. Practical Manual of Paleocene and Eocene Planktonic Foraminifera. In: Verga, D., Rettori, R. (Eds.). International school on Planktonic Foraminifera. Universities of Perugia and Milano. Tipografia Pontefelcino. Perugia, 152 pp.

Premoli Silva, I., Verga, D. 2004. Practical Manual of Cretaceous Planktonic Foraminifera. In: Verga, D., Rettori, R. (Eds), International school on Planktonic Foraminifera. Universities of Perugia and Milano. Tipografia Pontefelcino, Perugia, 283 pp.

Rahimi, S., Ashouri, A., Sadeghi, A., Ghaderi, A. 1979. Biostratigraphy of the Gurpi Formation Based on Planktonic foraminifera of the Gandab section and its correlation to the type section, Kabir Kuh anticline, Southwest of Iran. Journal of Research Stratigraphy and Sedimentology 72, 37-52.

Razmjooei, M.J., Thibault, N., Kani, A., Dinarès-Turell, J., Pucéat, E., Shahriari, S., Radmacher, W., Jamali, A.M., Ullmann, C.V., Voigt, S., Cocquerez, T. 2018. Integrated bioand carbon-isotope stratigraphy of the Upper Cretaceous Gurpi Formation (Iran): A new reference for the eastern Tethys and its implications for large-scale correlation of stage boundaries. Cretaceous Research 91, 312-340.

Robaszynski, F., Caron, M. 1995. Foraminifères planktoniques du Crétacé. Bulletin de la Société Géologique de France 166, 681-698.

Robaszynski, F. 1998. Planktonic foraminifera-Upper Cretaceous, Chart of Cretaceous Biochronostratigraphy. In: de Graciansky, P.C., Hardenbol, J., Vail, P.R. (Eds), Mesozoic and Cenozoic Sequence Stratigraphy of European Basins. Society For Sedimentary Geology (SEPM), Special Publication 60, 782 pp.

Robaszynski, F., González-Donoso. J.M., Linares. D., Amédro, F., Caron, M., Dupuis, C., Dhondt, A.V., Gartner, S. 2000. Le Crétacé Supérieur de la region de Kalaat Senan, Tunisie Centrale. Litho-biostratigraphie intégrée: zones d'ammonites, de foraminifères planctoniques et de nannofossiles du Turonien supérieur au Maastrichtien. Bulletin 
des Centres de Recherches Exploration-Production ElfAquitaine 22, 359-490.

Sadeghi, A., Darabi, Q. 2015. Biostratigraphy of the Gurpi Formation in Maroon Oilfield. Journal of Stratigraphy and Sedimentology Research 60, 19-36.

Sliter, W.V. 1989. Biostratigraphic zonation for Cretaceous planktonic foraminifers examined in thin section. The Journal of Foraminiferal Research 1, 1-19.

Vaziri-Moghaddam, H., Safari, A., Shahriari, S., Khazaei, A., Taheri, A. 2013. Biostratigraphy and Palaeoecology of the Maastrichtian Deposits (Tarbur and Gurpi Formations) at
Gardbishe Area (South of Borojen). Scientific Quarterly Journal (Geosciences) 87, 143-162.

Yıldız, A., Özdemir, Z. 1999. Biostratigraphic and isotopic data on the Çöreklik Member of the Hekimhan Formation (Campanian-Maastrichtian) of SE Turkey and palaeoenvironmental significance. Cretaceous Research 20, 107-117. Zepeda, M.A. 1998. Planktic Foraminifera Diversity, Equitability and Biostratigraphy of the Uppermost CampanianMaastrichtian, ODP Leg122, Hole 762, Exmoth Plateau, NW Australia, Eastern Indian Ocean. Cretaceous Research 19, 117-152. 